\title{
Evaluation of preemptive dexketoprofen trometamol effect on blood chemistry, vital signs and postoperative pain in dogs undergoing ovariohysterectomy
}

\author{
Saritas ZK ${ }^{1}$, Saritas $\mathrm{TB}^{2}$, Pamuk K ${ }^{1}$, Korkmaz $\mathrm{M}^{1}$, Yaprakci MV${ }^{1}$, Yilmaz $\mathrm{O}^{3}$, Demirkan ${ }^{1}$ \\ Afyon Kocatepe University, Faculty of Veterinary Medicine, Department of Surgery, Afyonkarahisar, Turkey. \\ zksaritas@hotmail.com
}

\begin{abstract}
Objective: To investigate the postoperative analgesic effects of preemptive dexketoprofen trometamol in dogs subjected to ovariohysterectomy (OHE).

Material and methods: Seventeen adult bitches of various breeds were used in this study. The dogs were randomly allocated into of two groups. Subjects in the dexketoprofen trometamol (DEX) group $(n=10)$, received intravenous (i.v.) dexketoprofen trometamol, $1 \mathrm{mg} / \mathrm{kg}, 15$ minutes before premedication, while those assigned to the control $(C)$ group $(n=7)$ were given no analgesics prior to premedication. Pain level was assessed by two researchers before the administration of anaesthesia (15 minutes before start) and 0, 1, 2, 4 and 6 hours after surgery. A modified University of Melbourne Pain Scale (UMPS) was used to evaluate pain in both groups. Results: Serum cortisol level changed from 0 to $1 \mathrm{~h}$ and from 0 to 1 to $4 \mathrm{~h}$ were compared between the groups; the increase in the $\mathrm{C}$ group was statistically significant. The modified UMPS was applied to both groups at baseline and postoperative 1, 2, 4 and $6 \mathrm{~h}$. According to this test, the values for DEX were significantly lower than controls at 4 and $6 \mathrm{~h}(\mathrm{p}<0.001)$.

Conclusion: Stable vital signs with unchanged biochemical parameters on dexketoprofen administration are a promising finding. The clinical advantage shown by the pain scale difference and the low serum cortisol levels should qualify dexketoprofen for preemptive pain management in dogs (Tab. 5, Fig. 2, Ref. 30). Text in PDF www.elis.sk. Key words: dexketoprofen trometamol, preemptive analgesia, dog, ovariohysterectomy.
\end{abstract}

\section{Introduction}

Preemptive analgesia is the preoperative prevention of pain, administered before wound associated nociceptors are stimulated, and the subsequent maintenance of analgesia. Several studies in humans confirmed that preemptive analgesia reduces postoperative pain and the need for analgesics (1-3). Perioperative elimination of pain facilitates recovery from anesthesia and increases patient well-being (4-6). Undesirable effects of postoperative pain in surgical patients, such as loss of appetite, self-trauma, maladaptive physiological response or maladaptive behaviour, prolong time to recovery (6-8).

Ketoprofen is a non-steroidal anti-inflammatory drug (NSAID) of the arylpropionic acid class with analgesic and antipyretic effects $(6,9)$. It has been widely used as an analgesic in dogs $(6,10$, $11)$. It acts by inhibiting cyclooxygenase enzyme-1 (COX-1) and/

${ }^{1}$ Afyon Kocatepe University, Faculty of Veterinary Medicine, Department of Surgery, Afyonkarahisar, Turkey, ${ }^{2} \mathrm{Necmettin}$ Erbakan University, Meram Medical School, Department of Anesthesiology and Reanimation, Konya, Turkey, and ${ }^{3}$ Afyon Kocatepe University, Faculty of Veterinary Medicine, Department of Obstetrics and Gynecology, Afyonkarahisar, Turkey

Address for correspondence: Z.K. Saritas, DVM, PhD, Afyon Kocatepe University, Faculty of Veterinary Medicine, Department of Surgery, 03200, Afyonkarahisar, Turkey.

Phone: +90.533 .6198622 , Fax: +90.272 .2281349$ /or COX-2, thereby inhibiting the synthesis of prostaglandins both in inflammatory processes and in healthy tissue $(6,12)$. Dexketoprofen trometamol is the water soluble salt of the S-isomer of ketoprofen, which is racemic $(13,14)$.

Few study reports are available on the analgesic efficacy of dexketoprofen in veterinary medicine (6).

In this study, the preemptive use of dexketoprofen trometamol was evaluated in dogs undergoing OHE for its effect on vital signs, some biochemical parameters and postoperative pain.

\section{Materials and methods}

\section{Animals}

Seventeen adult bitches of various breeds were used in this study. Animals were randomly divided into two groups, seven animals in the control (C), and ten in the dexketoprophen (DEX) group. Prior approval for the study was obtained from the Afyon Kocatepe University Ethical Committee; owners were informed and signed a voluntary consent for their animals to be included in the study.

\section{Methods}

Preemptive Analgesia

DEX group received $1 \mathrm{mg} / \mathrm{kg}$ dexketoprofen trometamol (Arveles ${ }^{\circledR}$, UFSA, Turkey) i.v. $15 \mathrm{~min}$. before premedication; no 
Tab. 1. Modified University of Melbourne Pain Scale (30).

\begin{tabular}{ll}
\hline Dog Name/ID: & \multicolumn{1}{c}{ Time Point: } \\
Breed: & \\
Category and descriptor Score & \\
\hline From outside the cage: & 0 \\
Vocalization (choose only one)* & \\
Not vocalizing & 1 \\
Slight vocalization but dysphoric & 2 \\
Intermittent vocalization & 3 \\
Continuous vocalization & 2 \\
\hline Posture & \\
a) Guarding or protecting affected area & 0 \\
b) Position (choose only one) & 1 \\
Lateral recumbency & 1 \\
Sternal recumbency & 2 \\
Sitting, standing, or comfortable & 1 \\
Standing with head hanging & 2 \\
Moving & \\
Abnormal posture and/or uncomfortable, continuous position change & 2
\end{tabular}

\begin{tabular}{lr}
\hline Activity (choose one) & \\
At rest & 0 \\
Sleeping & 0 \\
Semi-conscious & 1 \\
Awake & 0 \\
Eating & 2 \\
Restless (pacing continuously; getting up and down) & 3 \\
Rolling and thrashing &
\end{tabular}

From inside the cage:

Mental status (choose only one) ${ }^{* *}$ Baseline minus current score $=$ overall score

Too sedate to evaluate or dysphoric

Submissive

Uninterested in people (unusual for this dog)

Overtly friendly

Wary or Aggressive

Response to palpation (choose only one)***

Normal, allows palpation of surgical site

Allows but then moves away, tenses or looks when surgical area touched

Increased whining or painful expression when surgical area touched 2

Will not allow general surgical area to be touched

Vocalization (choose only one)*

Not vocalizing

Vocalizing but responds to quiet voice and/or stroking

Vocalizing when touched

Intermittent vocalization

Continuous vocalization

The minimum possible score is 0 ; the maximum possible score is 20 .

* Does not include alert barking.

** For this category, score recorded is the score obtained after surgery minus the score obtained before

surgery.

*** Palpate around the general surgical area starting at the dorsal end and working toward incision site.

other analgesics were administered to animals in either group before the 6 th postoperative hour.

\section{Anaesthesia}

Dogs were fasted 12 hours before the study. Atropine, $0.04 \mathrm{mg} /$ $\mathrm{kg}$, was injected s.c. 30 minutes prior to general anaesthesia. Premedication consisted in i.m. administration of $2 \mathrm{mg} / \mathrm{kg}$ Xylazin $\mathrm{HCl}$ (Rompun $2 \%$, Bayer, Germany) and general anaesthesia was achieved with Ketamine $\mathrm{HCl}$ (Alfamine 10 \%, Ege Vet, Turkey), $15 \mathrm{mg} / \mathrm{kg}$ i.m.

\section{Surgical procedure}

Following preparation for aseptic surgery, OHE was performed through a ventral midline approach. All OHE procedures were performed by same practitioner to avoid bias between the groups. Procedure duration was $30 \pm 5$ and $34 \pm 3 \mathrm{~min}$, respectively, in the control and DEX groups.

Biochemical analysis

Blood samples were collected for biochemical analysis at baseline ( $0 \mathrm{~min})$, and postoperative $1 \mathrm{st}, 2 \mathrm{nd}, 4 \mathrm{th}$ and 6 th hours. Total protein, urea, ALT, AST, ALB and GGT values were determined by an autoanalysis device (Cobes C 111, Roche, Germany). Serum cortisol levels at $0,1,4,6$ and 24 hours in venous blood samples were measured by an ELISA method.

\section{Vital parameters}

Heart rate (HR), respiratory rate (RR) and body temperature were measured preoperatively at baseline (T0), and at postoperative 0 (T1), 30 (T2), 60 (T3), 90 (T4), 240 (T5) and 360 (T6) minutes.

\section{Pain assessment}

The degree of pain was assessed 15 minutes before administration of anaesthesia and 0, 1, 2, 4 and 6 hours after surgery, by the same researchers. The modified UMPS was used for this evaluation in all dogs (Tab. 1).

\section{Statistical analysis}

Data were analyzed with the help of the SPSS for Windows, 16.0, using Student's t-test for paired samples and ANOVA for repeated measurements. Values were described by their average (mean) \pm Standard Deviation (SD). The p-value lower then 0.05 was considered to be statistically significant.

\section{Results}

The mean body weight was $16.1 \pm 7.7 \mathrm{~kg}$ and age $1.8 \pm 0.9$ years in $\mathrm{C}$, while in DEX the corresponding values were, respectively, $20.5 \pm 8.3 \mathrm{~kg}$ and $2 \pm 1$ years. Blood chemistry results are shown in Table 2. No statistically significant difference was detected between controls and DEX group at any time point for total protein, urea, ALT, ALB or GGT. An increase in AST from baseline to 1 hour in the DEX group was, however, significant, as also was the fall in the control group at 6 hours $(p<0.05$ for both).

The increase in serum cortisol levels of the control group from baseline to $1 \mathrm{~h}$ and to 1 and $4 \mathrm{~h}$ was significant $(\mathrm{p}<0.05)$. Cortisol levels increased at $6 \mathrm{~h}$ in the DEX group, with a statistically significant difference compared to controls $(\mathrm{p}<0.05)$. Cortisol levels at $24 \mathrm{~h}$ decreased again at $24 \mathrm{~h}$, approaching baseline values (Tab. 3, Fig. 1).

Vital sign measurements are summarized in the Table 4. Heart rate was significantly increased at $90 \mathrm{~min}$. in the DEX group, while an increase in control animals at 360 min compared to DEX was also found statistically significant $(p<0.05)$. A fall in body temperature in the DEX group at postoperative 0 min compared to 
Tab. 2. Blood Chemistry Values in the Control $(n=7)$ and Dexketoprofen $(n=10)$ Group Dogs (mean \pm SD).

\begin{tabular}{|c|c|c|c|c|c|c|}
\hline Time/Group & $\begin{array}{l}\text { Total Protein } \\
\text { (g/dL) }\end{array}$ & $\begin{array}{l}\text { Albumin } \\
(\mathrm{g} / \mathrm{dL})\end{array}$ & $\begin{array}{l}\text { Urea } \\
(\mathrm{mg} / \mathrm{dl})\end{array}$ & $\begin{array}{c}\text { ALT } \\
\text { (IU/L) }\end{array}$ & $\begin{array}{c}\text { AST } \\
\text { (IU/L) }\end{array}$ & $\begin{array}{c}\text { GGT } \\
(\mathrm{IU} / \mathrm{L})\end{array}$ \\
\hline \multicolumn{7}{|l|}{ Baseline (Preop.) } \\
\hline Control & $6.8 \pm 0.7$ & $2.9 \pm 0.1$ & $9.8 \pm 0.3$ & $28.1 \pm 1.8$ & $31.4 \pm 5.4^{\mathrm{cd}}$ & $2.1 \pm 0.7$ \\
\hline Dexketoprofen & $6.1 \pm 0.2$ & $3.1 \pm 0.1$ & $9.6 \pm 1.2$ & $22.3 \pm 2$ & $26 \pm 1.8^{\mathrm{d}}$ & $4.8 \pm 0.7$ \\
\hline \multicolumn{7}{|l|}{ Postop. $1 \mathrm{~h}$} \\
\hline Control & $7.3 \pm 0.7$ & $3 \pm 0.1$ & $10.9 \pm 0.6$ & $30.1 \pm 2.4$ & $37 \pm 7.3^{\text {cd }}$ & $3.2 \pm 0.7$ \\
\hline Dexketoprofen & $6.5 \pm 0.3$ & $3.3 \pm 0.1$ & $10.8 \pm 1.2$ & $23.9 \pm 2.3$ & $31.2 \pm 1.8^{\mathrm{cd}}$ & $3.8 \pm 0.4$ \\
\hline \multicolumn{7}{|l|}{ Postop. $2 \mathrm{~h}$} \\
\hline Control & $7.4 \pm 0.5$ & $3.1 \pm 0.1$ & $13.4 \pm 0.6$ & $31.6 \pm 2$ & $56.5 \pm 8.5^{\mathrm{bc}}$ & $3.5 \pm 0.8$ \\
\hline Dexketoprofen & $5.7 \pm 0.2$ & $3 \pm 0.1$ & $13.5 \pm 1$ & $23.6 \pm 2.4$ & $57.9 \pm 5^{\mathrm{bc}}$ & $3.7 \pm 0.5$ \\
\hline \multicolumn{7}{|l|}{ Postop. $4 \mathrm{~h}$} \\
\hline Control & $7.0 \pm 0.5$ & $3 \pm 0.1$ & $14.6 \pm 1$ & $32.7 \pm 1.7$ & $59.1 \pm 7.4^{\mathrm{bc}}$ & $3.4 \pm 0.7$ \\
\hline Dexketoprofen & $5.6 \pm 0.2$ & $3 \pm 0.1$ & $14.1 \pm 1.3$ & $23.5 \pm 2.1$ & $70.4 \pm 7.3^{\mathrm{b}}$ & $3.1 \pm 0.7$ \\
\hline \multicolumn{7}{|l|}{ Postop. $6 \mathrm{~h}$} \\
\hline Control & $6.8 \pm 0.5$ & $2.8 \pm 0.1$ & $11.5 \pm 1.3$ & $31.5 \pm 2$ & $46.7 \pm 6.8^{\mathrm{bcd}}$ & $2.2 \pm 0.6$ \\
\hline Dexketoprofen & $5.8 \pm 0.2$ & $3 \pm 0.9$ & $14.9 \pm 2.2$ & $24.8 \pm 2.3$ & $71.3 \pm 9^{\mathrm{b}}$ & $3.3 \pm 0.5$ \\
\hline
\end{tabular}

$\overline{\mathrm{a}, \mathrm{b}, \mathrm{c}, \mathrm{d}}$ Indicates a statistical difference between or among values marked by the same letter in the same column $(\mathrm{p}<0.05)$.

Tab. 3. Serum Cortisol Levels in Control and Dexketoprofen Group Dogs (mean \pm SD).

\begin{tabular}{ll}
\hline Time/Group & $\begin{array}{c}\text { Cortisol } \\
\mathrm{mcg} / \mathrm{ml}\end{array}$ \\
\hline Baseline & $14.2 \pm 2.2^{\mathrm{c}}$ \\
$\quad$ Control & $34.6 \pm 7.3^{\mathrm{bc}}$ \\
$\quad$ Dexketoprofen & $51 \pm 10.9^{\mathrm{abc}}$ \\
\hline $1 \mathrm{~h}$ & $34.2 \pm 7.1^{\mathrm{bc}}$ \\
$\quad$ Control & $66.4 \pm 11.6^{\mathrm{ab}}$ \\
$\quad$ Dexketoprofen & $50.6 \pm 9.5^{\mathrm{abc}}$ \\
\hline $4 \mathrm{~h}$ & \\
Control & $35.9 \pm 2.7^{\mathrm{cd}}$ \\
Dexketoprofen & $84.9 \pm 39.3^{\mathrm{a}}$ \\
\hline h & \\
$\quad$ Control & $15.9 \pm 1.2^{\mathrm{c}}$ \\
Dexketoprofen & $28.5 \pm 9.2^{\mathrm{bc}}$ \\
\hline Control & \\
$\quad$ Dexketoprofen & \\
\hline
\end{tabular}

baseline was also significant $(\mathrm{p}<0.05)$. Body temperatures returned to baseline values at $360 \mathrm{~min}$ in both groups.

Modified UMPS score evolution is shown in the Table 5 and Figure 2 . They were significantly lower in the DEX group at 4 and 6 hours compared to the control group $(\mathrm{p}<0.001)$.

\section{Discussion}

Ovariohysterectomy is a surgical procedure widely used in analgesic studies in dogs, since it causes moderate or severe postoperative pain $(6,15)$.

Surgical trauma activates COX-2 and prostaglandin synthesis, respectively intervening in peripheral and central nervous system sensitization. Inhibition of COX-2 up-regulation plays a key role in the analgesic effect of preoperatively administered NSAID (16).

Ketoprofen is a racemic mixture of two enantiomers. The main enantiomer, dexketoprofen [S(+)-ketoprofen], is responsible for its analgesic effect while causing fewer adverse effects than racemic ketoprofen $(6,13,17)$. In human practice, dexketoprofen is used for postoperative analgesia by the oral (18), intramuscular (19,

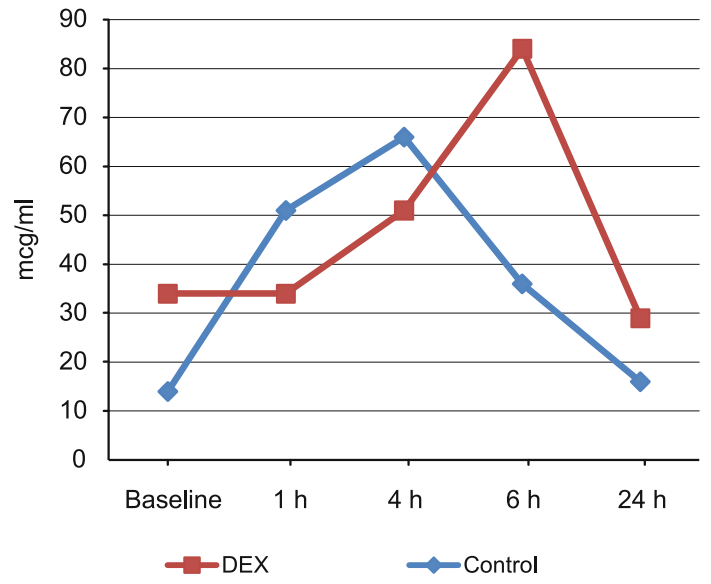

Fig. 1. Serum Cortisol Levels in Control and DEX Group dogs.

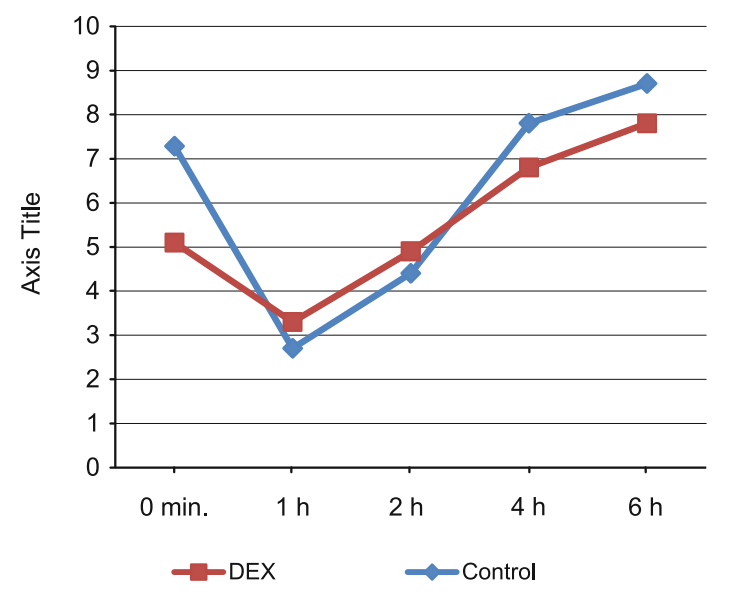

Fig. 2. Pain Scores in Control and DEX Group Dogs (modified University of Melbourne Pain Scale).

$20)$ or intravenous routes $(21,22)$. The addition of trometamol to dexketoprofen increases the absorption rate after oral administration achieving maximum plasma concentration sooner than ketoprofen and dexketoprofen. Parenteral application is more ad- 


\section{1-195}

Tab. 4. Vital Parameters in Control and Dexketoprofen Group Dogs (mean \pm SD).

\begin{tabular}{|c|c|c|c|}
\hline Time/Group & $\begin{array}{l}\text { Heart Rate } \\
\text { (Pulse/Min) }\end{array}$ & $\begin{array}{l}\text { Respiratory Rate } \\
\text { (Min) }\end{array}$ & $\begin{array}{c}\text { Body Temperature } \\
\left({ }^{\circ} \mathrm{C}\right)\end{array}$ \\
\hline \multicolumn{4}{|l|}{ T0 / Baseline } \\
\hline Control & $85.8 \pm 4.7^{\mathrm{bc}}$ & $19.4 \pm 0.9$ & $38.6 \pm 0.3^{\mathrm{a}}$ \\
\hline Dexketoprofen & $95.2 \pm 6.9^{\mathrm{abc}}$ & $27.4 \pm 4.5$ & $38.3 \pm 0.09^{\mathrm{abc}}$ \\
\hline \multicolumn{4}{|l|}{ T1 } \\
\hline Control & $77.7 \pm 3.6^{\mathrm{bc}}$ & $18.5 \pm 1$ & $38.2 \pm 0.3^{\mathrm{abc}}$ \\
\hline Dexketoprofen & $87.8 \pm 7.5^{\mathrm{bc}}$ & $21.2 \pm 2.8$ & $38.02 \pm 0.2^{\text {abcd }}$ \\
\hline \multicolumn{4}{|l|}{$\mathrm{T} 2$} \\
\hline Control & $74.7 \pm 2^{\mathrm{c}}$ & $17.1 \pm 1$ & $37.8 \pm 0.2^{\mathrm{bcd}}$ \\
\hline Dexketoprofen & $78.6 \pm 4.7^{\mathrm{bc}}$ & $20.9 \pm 1.9$ & $37.9 \pm 0.2^{\mathrm{abcd}}$ \\
\hline \multicolumn{4}{|l|}{$\mathrm{T} 3$} \\
\hline Control & $79.5 \pm 2.3^{\mathrm{bc}}$ & $20 \pm 4.1$ & $37.3 \pm 0.17^{\mathrm{d}}$ \\
\hline Dexketoprofen & $74.7 \pm 3.5^{\mathrm{c}}$ & $18.8 \pm 2.1$ & $37.9 \pm 0.28^{\mathrm{bcd}}$ \\
\hline \multicolumn{4}{|l|}{$\mathrm{T} 4$} \\
\hline Control & $83.5 \pm 4^{\mathrm{bc}}$ & $20.4 \pm 2.3$ & $37.7 \pm 0.17^{\mathrm{cd}}$ \\
\hline Dexketoprofen & $92.5 \pm 7.6^{\mathrm{abc}}$ & $20.1 \pm 1.3$ & $37.8 \pm 0.2^{\mathrm{bcd}}$ \\
\hline \multicolumn{4}{|l|}{ T5 } \\
\hline Control & $90.5 \pm 6.4^{\mathrm{bc}}$ & $19.7 \pm 1.2$ & $38.1 \pm 0.18^{\mathrm{abc}}$ \\
\hline Dexketoprofen & $111 \pm 9.4^{\mathrm{a}}$ & $22.4 \pm 2.3$ & $37.8 \pm 0.28^{\mathrm{bcd}}$ \\
\hline \multicolumn{4}{|l|}{ T6 } \\
\hline Control & $92 \pm 3.7^{\mathrm{abc}}$ & $20.5 \pm 0.5$ & $38.5 \pm 0.16^{\mathrm{ab}}$ \\
\hline Dexketoprofen & $98.7 \pm 6.5^{\mathrm{ab}}$ & $20.8 \pm 1.9$ & $38.1 \pm 0.11^{\mathrm{abc}}$ \\
\hline
\end{tabular}

Tab. 5. Postoperative modified University of Melbourne Pain Scale (UMPS) scores in Control and Dexketoprofen Group Dogs.

\begin{tabular}{lcc}
\hline Time & $\begin{array}{c}\text { Control Group } \\
(\mathrm{n}=7)\end{array}$ & $\begin{array}{c}\text { Dexketoprofen Group } \\
(\mathrm{n}=10)\end{array}$ \\
\hline -15 $\mathrm{min}^{+}$/ Baseline & $7.28 \pm 1.04$ & $5.1 \pm 0.6^{*}$ \\
Postop. 1 h & $2.7 \pm 0.4$ & $3.3 \pm 0.3$ \\
Postop. 2 h & $4.4 \pm 0.9$ & $4.9 \pm 0.4$ \\
Postop. 4 h & $7.8 \pm 1.1$ & $6.8 \pm 0.7^{*}$ \\
Postop. 6 h & $8.7 \pm 1.3$ & $7.8 \pm 0.9^{*}$ \\
${ }^{+}:$-15 min: 15 minutes before dexketoprofen administration \\
${ }^{*} \mathrm{p}<0.001$
\end{tabular}

vantageous, however, in patients undergoing general anaesthesia considering the ease of administration.

In the study by Morgaz et al (6), in dogs buprenorfin, dexketoprofen or tramadol were given preoperatively to prevent postoperative pain in dogs. HR and RR were recorded every $15 \mathrm{~min}$ for 120 min during the procedure. No statistical difference was observed among the measurements of the three groups. In our study, HR, RR and body temperature were recorded before surgery $0,30,60,90,240$ and 360 minutes thereafter. HR increased significantly at $90 \mathrm{~min}$. in the DEX group. On the other hand, an inversion of the situation at $360 \mathrm{~min}$ with HR increase in controls was also statistically significant. Intraoperative measurements were disregarded in this study due to the short surgery duration (30 min).

Body temperature, recorded in our study, was not available in Morgaz et al (6). In the DEX group, the decrease from baseline at postoperative 0 min was statistically significant. In both groups, body temperatures returned to baseline 360 minutes after surgery.

Respiratory values did not vary in either group at any time point.
There is no previous reports of blood chemistry parameters in dogs given dexketoprofen. In our study, both groups were evaluated for total protein, urea, ALT, AST, ALB and GGT before surgery and 1, 2, 4 and $6 \mathrm{~h}$ thereafter. The AST values were shown to have increased significantly in the DEX group from baseline to 1 hour after surgery; a decrease of the same enzyme level in the control group at 6 hours was also significant. The other measurements varied in both groups while remaining within their normal ranges.

The International Association for the Study of Pain (IASP) defines pain as "an unpleasant sensory and emotional experience associated with actual or potential tissue damage, or described in terms of such damage". Several metabolic alterations are known to occur as the result of pain. The most important changes are the increase in the levels of stress hormones noradrenaline, adrenaline, cortisol and ACTH (23). Serum cortisol levels were measured in this study; the control group values were significantly elevated at postoperative 1 and $4 \mathrm{~h}$ with respect to baseline. This result is interpreted as a reduction of postoperative pain by dexketoprofen. As cortisol levels and their variation have not previously been measured in related studies, this should be seen as a relevant finding.

Ketoprofen, an NSAII, is used postoperatively in dogs for its nonselective COX inhibition $(6,24)$. Luna et al $(25)$ studied the negative effects of the chronic use of ketoprofen, etodolac, meloxicam, caprofen and flunixin. They reported that ketoprofen and etodolac increase clotting time, predisposing patients to gastrointestinal bleeding. This effect on hemostasis also creates a surgical handicap by increasing the chances of intraoperative bleeding $(6,24)$. Some writers reported, however, that this defect has no clinical relevance $(6,26)$. In human medicine, dexketoprofen is considered as an excellent analgesic (22).

In this study, vital signs and a set of biochemical parameters showed limited variation in dogs given preemptive dexketoprofen. Its relevance for clinical practice is in its being the second report on the issue, following that of Morgaz et al (6).

Adverse effects linked to NSAII are primarily renal, gastrointestinal and coagulation disorders. None of these were encountered in the first week of the study by Morgaz et al (6). No intraoperative or postoperative bleeding or diarrhoae was seen in the experimental group in our study.

Pain measurement is a subjective procedure in veterinary medicine, as it may be in neonatology. The veterinary anaesthesiologist is obliged to evaluate behaviour to assess postoperative pain (6). Different pain scales are used in veterinary medicine. Moll et al (27) used s.c. and transdermal buprenorphin as a preemptive analgesic in dogs undergoing OHE, evaluating postoperative pain by a modified UMPS. A study of epidural morphine and transdermal fentanyl in OHE dogs (28) postoperative analgesic efficacy was estimated by a modified scale used by both Grisneaux et al. (10) and Robinson et al (29). As for Morgaz et al (6), they used two different evaluation systems for postoperative pain evaluation: a dynamic and interactive visual analog scale (DIVAS) and the shortform Glasgow Composite Measure Pain Score (CMPS-SF). The study here reported used the modified UMPS for 6 hours following surgery; the score was found significantly lower in the DEX group compared to controls at the postoperative 4th and 6th hours. 


\section{Conclusion}

Considering its ease of administration, the stability of vital signs and the absence of major changes in blood chemistry, as well as the lower serum cortisol levels and the lower pain scores in the DEX group, we conclude that dexketoprofen trometamol may be used in the preemptive management of postoperative pain in dogs.

\section{References}

1. Vallejo MC, Phelps AL, Sah N, Romea RC, Falks JS, Johnson RR, Kenan DM, Bonaventura MA, Edington HD. Preemptive analgesia with bupivacaine for segmental mastectomy. Reg Anesth Pain Med 2006; 31 : 227-232.

2. Dahl JB, Kehlet H. Non steroidal anti-inflammatory drugs: Rationale for use in severe postoperative pain. Br J Anaesth 1991; 66: 703-712.

3. Tuncer S, Tavlan A, Köstekçi H, Reisli R, Otelcioğlu S. Postoperatif ağrıda deksketoprofen kullanımı. Ağrı 2006; 18 (3): 30-35.

4. Bonnet F, Marret E. Influence of anaesthetics and analgesic techniques on outcome after surgery. British journal of Anaesthesia 2005; 95: 52-58.

5. Wagner AE Worland GA, Glawe JC, Hellyer PW. Multycenter, randomized controlled trial of pain-related behaviors following routine neutering in dogs. J Am Vet Med Assoc 2008; 233; 109-115.

6. Morgaz J, Navarrete R, Munoz-Rascon P, Dominguez JM, Fernandez-Sarmiento JA. Postoperative analgesic effects of dexketoprofen, burenorphine and tramadol in dogs undergoing ovariohysterectomy. Research in Vet Sci 2013; 95: 278-282.

7. Mathews KA. Pain assessment and general approach to management. The Veterinary Clinics of North America. Small Animal Practice 2000; 30: 729-755.

8. Pascoe PJ. Perioperative pain management. Vet Clin North Am Small Anim Pract 2000; 30: 917-932.

9. Piparot P, Dupuis J, Grisneaux E, Cuvelliez S, Plante J, Beauregard G, Bonneau NH, Bouffard J, Blais D. Comparison of ketoprofen, oxymorphone hydrochloride, and butorphanol in the treatment of postoperative pain in dogs. J Am Vet Med Assoc 1997; 211: 438-444.

10. Grisneaux E, Pibarot P, Dupuis J, Blais D. Comparison of ketoprofen and carprofen administered prior to orthopedics surgery for control of postoperative pain in dogs. J Am Vet Med Assoc 1999; 215: 1105-1110.

11. Lemke KA, Runyon CL, Horney BS. Effects of preoperative administration of ketoprofen on anesthetic requirements and signs of postoperative pain in dogs undergoing elective ovariohyterectomy. J Am Vet Med Assoc 2002; 221: 1268-1275.

12. Streppa HK, Jones CJ, Budsberg SC. Cyclooxygenase selectivity of nonsteroidal anti-inflammatory drugs in canine blood. Am J Vet Res 2002; 63: 91-94.

13. Mauleón D, Artigas R, García ML, Carganico G. Preclinical and clinical development of dexketoprofen. Drugs 1996; 52 (Suppl 5): 24-45.

14. Leman P, Kapadia Y, Herington J. Randomised controlled trial of the onset of analgesic efficacy of dexketoprofen and diclofenac in lower limb. Emerg Med J 2003; 20: 511-513.

15. Slingsby LS, Taylor PM, Murrell JC. A study to evaluate buprenorphine at $40 \mathrm{mcg} \mathrm{kg}(-1)$ compared to $20 \mathrm{mcg} \mathrm{kg}(-1)$ as a post-operative analgesic in the dog. Vet Anaesth Analg 2011; 38: 584-593.
16. Kara İ, Tuncer S, Erol A, Reis R. The effects of preemptive dexketoprofen use on postoperative pain relief and tramadol consumption. Agri 2011; 23 (1): 18-21.

17. Neirinckx E, Croubels S, De Boever S, Remon JP, Bosmans T, Daminet S, De Backer P, Vervaet C. Species comparison of enantioselective oral bioavailability and pharmacokinetics of ketoprofen. Res Vet Sci 2011; 91: 415-421.

18. Iohom G, Walsh M, Higgins G, Shorten G. Effect of perioperative administration of dexketoprofen on opioid requirements and inflammatory response following elective hip arthroplasty. $\mathrm{Br} \mathrm{J}$ Anaesth 2002; 88 (4): 520-526.

19. Jamdade PT, Porwal A, Shinde JV, Erram SS, Kamat VV, Karmarkar PS, Bhagtani K, et al. Efficacy and tolerability of intramuscular dexketoprofen in postoperative pain management following hernia repair surgery. Anesthesiol Res Pract 2011; 12: 1-5.

20. Hanna MH, Elliott KM, Stuart-Taylor ME, Roberts DR, Buggy D, Arthurs GJ. Comparative study of analgesic efficacy and morphine-sparing effect of intramuscular dexketoprofen trometamol with ketoprofen or placebo after major orthopedic surgery. Br J Clin Pharmacol 2003; 55 (2): 126-133.

21. Zippel H, Wagenitz A. Comparison of the efficacy and safety of intravenously administered dexketoprofen trometamol and ketoprofen in the management of pain after orthopaedic surgery: A multicentre, double-blind, randomised, paralel-group clinical trial. Clin Drug Investig 2006; 26: 517-528.

22. Yazar MA, Inan N, Ceyhan A, Sut E, Dikmen B. Postoperative analgesic efficacy of intravenous dexketoprofen in lumbar disc surgery. Journal of Neurosurgical Anesthesiology 2011; 23: 193-197.

23. Erol M. Izci C. Postoperative analgesic effects of Carprofen following osteotomy and laparatomy in dogs. J Anim Vet Adv 2011; 10 (7): 922-927.

24. Lamont LA, Mathews KA. Opiods, nonsteroidal anti-inflammatories and analgesic adjuvants. 241-272. In: Tranquilli WJ, Thurmon JC, Grimm KA(Eds. Lumb and Jones' Veterinary Anesthesia and Analgesia. Blackwell Publishing, Iowa, 2007.

25. Luna SP, Basílio AC, Steagall PV, Machado LP, Moutinho FQ, Takahira RK, Brandão CV. Evaluation of adverse effects of long-term oral administration of carprofen, etodolac, flunixin meglumine, ketoprofen, and meloxicam in dogs. Am J Vet Res 2007; 68: 258-264.

26. Deneuche AJ, Dufayet C, Goby L, Fayolle P, Desbois C. Analgesic comparison of meloxicam or ketoprofen for orthopedic surgery in dogs. Vet Surgery 2004; 33: 650-660.

27. Moll X, Fresno L, Garcia F, Prandi D, Andaluz A. Comparison of Subcutaneous and transdermal administration of buprenorphine for preemptive analgesia in dogs undergoing elective ovariohysterectomy. Vet J 2011; 187: 124-128.

28. Pekcan Z, Koç B. The post-operative analgesic effects of epidurally administered morphine and transdermal fentanyl patch after ovariohysterectomy in dogs. Vet Anaesth Analg 2010; 37: 557-565.

29. Robinson TM, Kruse-Elliott KT, Markel MD, Pluhar GE, Massa $\mathbf{K}$, Bjorling DE. A comparison of transdermal fentanyl versus epidural morphine for analgesia in dogs undergoing major orthopedic surgery. J Am Anim Hosp Assoc 1999; 35: 95-100.

30. Odette $\mathbf{O}$, Lesley JS. A comparison of epidural analgesia provided by bupivacaine alone, bupivacaine + morphine, or bupivacaine + dexmedetomidine for pelvic orthopedic surgery in dogs. Vet Anaesth Analg, 2013; $40 ; 527-536$.

Received September 16, 2013. Accepted October 1, 2013. 